EMILIA LIV KOPEĆ 1

\title{
Spór Allana Blooma i Marthy Nussbaum o model kształcenia ogólnego a edukacja prawnicza
}

\section{Streszczenie}

Tekst stanowi kontekstową analizę myśli dotyczących edukacji ogólnej dwóch współczesnych filozofów - Alana Blooma i Marthy Nussbaum - oraz omawia możliwość praktycznej ich realizacji na gruncie polskiej edukacji prawniczej. Stanowi zatem jednocześnie konstruktywną krytykę dzisiejszego kształcenia prawników. Autorka przybliża poglądy konserwatywnego Alana Blooma zawarte w książce Umysł zamknięty - o tym, jak amerykańskie szkolnictwo wyższe zawiodło demokrację i zubożyło dusze dzisiejszych studentów i konfrontuje je następnie z nowoczesną myślą Marthy Nussbaum, ujętą przede wszystkim w W trosce o czlowieczeństwo - klasyczna obrona reformy kształcenia ogólnego. Kontekstem dla prowadzonych rozważań jest edukacja ogólna oraz prawnicza w Polsce. Analizie poddawana jest możliwość praktycznej realizacji postulatów obojga filozofów. Ponadto wskazane są istniejące już rozwiązania, stanowiące odzwierciedlenie prezentowanych idei. Na podstawie ogólnych rozważań formułowane są konkretne postulaty możliwe do wcielenia w życie w polskiej edukacji prawniczej. Ponadto oceniane są możliwe konsekwencje każdego z nich.

Słowa kluczowe: edukacja prawnicza, Alan Bloom, Martha Nussbaum

1 Emilia Liv Kopeć - Wydział Prawa, Administracji i Ekonomii Uniwersytetu Wrocławskiego, Królewski Instytut Technologiczny w Sztokholmie; e-mail: kopecemilia@gmail.com. 
EMILIA LIV KOPEĆ

\title{
The dispute between Allan Bloom and Martha Nussbaum over the model of general and legal education
}

\begin{abstract}
The article presents the contextual analysis of the thoughts on general education of two great minds of our times - Alan Bloom's and Martha Nussbaum's. It also states the possibilities of applying those ideas into polish legal education system. Therefore the article is not only a comparative study, but also the constructive criticism of legal education. Author basis is mainly the Bloom's „The Closing of the American Mind" and Nussbaum's "Cultivating Humanity: A Classical Defense of Reform in Liberal Education". The context of the analysis is the polish legal education. Author shows the possible practical applications of presented ideas into polish legal education and predicts its consequences. Moreover the existing solutions which follow their thoughts are indicated.
\end{abstract}

Keywords: legal education, Alan Bloom, Martha Nussbaum 
$\mathrm{D}$ oświadczenia związane ze szkolnictwem wyższym XX wieku - od mowy rektorskiej Heideggera poprzez wyzwolenie się czarnych studentów (w latach 60.) po popularyzację idei edukacji liberalnej - były i są nadal szeroko komentowane wśród intelektualistów. Najgłośniejszym, a zarazem jednym z najbardziej merytorycznych sporów jest dyskusja sprowokowana w 1987 roku wydaniem Umystu zamkniętego - O tym jak amerykańskie szkolnictwo wyższe zawiodto demokrację $i$ zubożyło dusze dzisiejszych studentów Allana Blooma. Poglądy tego słynnego, nieżyjącego już filozofa ukształtował przede wszystkim Leo Strauss, który był jego pierwszym mentorem na wymarzonych studiach na University of Chicago. Podczas swojej edukacji Bloom uległ przede wszystkim wpływom klasycznych myślicieli greckich oraz takich filozofów jak Rousseau, Machiavelli czy Hegel. W Umyśle zamkniętym, pozostającym do dziś obowiązkową pozycją na półce współczesnych konserwatystów, diagnozuje stan szkolnictwa wyższego na podstawie własnych doświadczeń studenta i nauczyciela oraz stawia tezę o kryzysie nie tylko na uniwersytetach, ale też w całym życiu intelektualnym Amerykanów. Książka Blooma spotkała się z falą krytyki właściwie większości środowisk, w tym również konserwatywnych ${ }^{2}$, lecz najbardziej wnikliwą krytyką pozostaje wydana w 1997 roku W trosce o człowieczeństwo - klasyczna obrona reformy kształcenia ogólnego Marthy Nussbaum, która jest jednym z czołowych przedstawicieli współczesnej myśli liberalnej. Recenzja książki Blooma pt. Undemocratic Vistas ${ }^{3}$, która ukazała się w 1987 na łamach The New York Review of Books stanowiła jedynie przyczynek do prac nad jeszcze szerszą krytyką - której efektem jest wspomniana książka. Ta amerykańska filozof, której zainteresowania ukształtowała przede wszystkim - odpowiednio interpretowana - myśl Arystotelesa oraz Johna Rawlsa jest dziś jednym z najbardziej wpływowych myślicieli na świecie. Jej odpowiedź na Umyst zamknięty Blooma jest logicznie uporządkowanym wywodem, popartym wieloma przykładami z amerykańskich uniwersytetów, przedstawiającym w zupełnie innym świetle szkolnictwo wyższe w USA.

2 Zob. seria krytycznych artykułów w jednym z numerów czasopisma „Interpretation - a Journal of Political Philosophy" 1988, 1, 16: W.A. Galston, Socratic Reason and Lockean Rights. The Place of the University in a Liberal Democracy; H.V. Jaffa, Humanizing Certitudes and Impoverishing Doubts; R.D. Master, Philosophy, Science, and the Opening of the American Mind; W. Morrisey, How Bloom Did It; H. Neumann, The Closing of the Philosophic Mind oraz R.L. Stone, Essays on Closing of the American Mind, Chicago 1989, passim.

3 M. Nussbaum, Undemocratic Vistas, http://www.nybooks.com/articles/archives/1987/nov/05/undemocratic-vistas/ (15.01. 2016), passim. 
Swój wywód poprowadzę od różnic na bardziej ogólnym gruncie, by stopniowo zawęzić zakres rozważań do edukacji i edukacji prawniczej. Pragnę zwrócić uwagę, iż spór Blooma i Nussbaum dotyczy formuły nauczania na etapie collage'u - tj. pierwszego stopnia, którego efektem jest ogólne wykształcenie studentów. Specjalizację młodzi Amerykanie zdobywają na drugim etapie - graduate school. Aby przeszczepić proponowane koncepcje do modelu polskiej edukacji bez przebudowywania fundamentów systemu szkolnictwa, uznaję zatem, iż należałoby je włączyć do istniejącego jednolitego programu studiów.

Fundamentalne różnice między koncepcjami Blooma i Nussbaum dobrze odzwierciedla ich spojrzenie na kulturę. Konserwatysta zwraca uwagę na fakt, iż w obecnym rozumieniu słowo „kultura” oznacza właściwie dowolną zbiorowość lub zjawisko o wspólnej cesze, sprawiając, iż kultura utraciła swój elitarny wymiar i przestała nią być w kantowskim rozumieniu - przestała być wytworem człowieka utalentowanego. Ironicznie zauważa, że upadek kultury w dzisiejszym świecie jest również uważany za kulturę. Mnogość i nazywanie wszystkiego kulturą w imię powszechnej równości sprawia, iż każda z nich domaga się uwagi i studiowania ${ }^{4}$. Nussbaum rozwija ten aspekt, formułując pięć swoistych postulatów nauczania kultury ${ }^{5}$, wskazujących, w jaki sposób należy poznawać te nowe byty: w konfrontacji nie należy zapominać o wewnętrznej różnorodności danej kultury, przedstawiać różne stanowiska względem praktyk w nich występujących, skupiać się na typowym przedstawicielu, a nie na najbardziej wybitnych jednostkach, czy też umiejętności dostrzegania i analizowania jej wieloaspektowości.

Zainteresowanie Nussbaum tym, co przez Blooma uznane jest za destrukcyjne dla kondycji intelektualnej Amerykanów wynika z jej przeświadczenia, iż zgłębianie problemów innych ludzi przyczynia się do budowania kompetencji obywatelskiej, niezbędnej dla świadomego i twórczego funkcjonowania człowieka w społeczeństwie demokratycznym i multikulturowym, jakim są Stany Zjednoczone. Nussbaum gloryfikuje instytucję demokracji, zarówno sensu largo - jako ustroju państwowego, oraz sensu stricto - na uczelniach. Uważa, że kształcenie wyższe powinno mieć charakter powszechny, które w efekcie przyczyniłoby się do budowania oraz umocnienia wspomnianej już kompetencji obywatelskiej ${ }^{6}$. Jest to swoista refutacja jednej z tez Umystu zamkniętego - wg Blooma jednym z celów istnienia uniwersytetu jest przyczynianie się do zapobiegania bądź leczenia "typowo demokratycznej

4 A. Bloom, Umyst zamknięty - o tym, jak amerykańskie szkolnictwo wyższe zawiodto demokrację i zubożyło dusze dzisiejszych studentów, Poznań 1997, s. 222-229.

5 M. Nussbaum, W trosce o człowieczeństwo - klasyczna obrona reformy ksztatcenia ogólnego, Wrocław 2008, s. 139-140.

6 Ibidem, s. 73. 
ślepoty"7. Nadmierne pielęgnowanie zasady równości doprowadziło do zawyżonego mniemania o sobie Amerykanów i niemalże kompletnego pozbawienia ich możliwości podejmowania szerokiej i wnikliwej refleksji. Nadto Bloom uważa, iż klasycy poparliby arystokrację - zarówno w sensie formy ustroju, jak i uniwersyteckiej. Wolą starożytnych uczonych były rządy rozumu, a jedynie filozofowie są mu w pełni oddani (dlatego to właśnie oni powinni rządzić) ${ }^{8}$. Bloom zwraca też uwagę na chaos, do którego przyczyniła się demokracja - wspomina tutaj m.in. wydarzenia lat $60 .$, tj. walki o równouprawnienie czarnoskórych obywateli, które miały miejsce również w uniwersyteckim wymiarze. Przytacza historię grożenia śmiercią białym nauczycielom akademickim przez ich czarnoskórych studentów. Stawia tezę, iż demokracja przyczyniła się do poddania się prymatu rozumu prymatowi równości, który nie jest w stanie zbliżyć nas do prawdy, a jedynie powoduje godzenie się na "demontaż struktury racjonalnych dociekań". Wskazuje najlepsze wg niego rozwiązanie tego problemu - hierarchizację, która okiełznałaby powstały chaos i przywróciła zasłużone centralne miejsce rozumowi ${ }^{9}$. Propozycja Nussbaum jest zupełnie odwrotna - zmierza do zwiększenia stopnia integracji studentów z wykładowcami, postuluje m.in. jak najbliższe poznanie indywidualności studenta celem przystosowania stawianych mu zadań jego personalnym możliwościom intelektualnym i umożliwienie samodzielnych krytycznych poszukiwań. Wprowadzenie w życie propozycji Nussbaum wymagałoby dużego autorytetu i kompetencji nauczyciela. Mniejsze grupy - 15-20-osobowe powodują ponadto konieczność większego zaangażowania ${ }^{10}$. Tego typu reforma i zespolenie się studentów z nauczycielami mogłyby przynieść ogromne korzyści we wspieraniu zdolnych i ambitnych jednostek, jednakże moim zdaniem największą przeszkodę dla powodzenia tego typu zmian Bloom wskazuje przy innym temacie - zwraca uwagę na ogromną liczbę nietwórczych pracowników naukowych ${ }^{11}$. Podobna sytuacja występuje również w Polsce - nie należałoby zatem oczekiwać zaangażowania nauczycieli w nauczanie studentów, jeżeli nie są oni zainteresowani nawet „własną", wybraną przez siebie dyscypliną naukową.

7 "Demokratyczną ślepotą" Bloom określa pogoń za egalitaryzmem, próby równego traktowania każdej odmienności - przy jednoczesnym braku teoretycznej refleksji nad przemyśleniami klasyków. Zob. A. Bloom, Umysł..., s. 299.

$8 \quad$ Ibidem, s. 337.

9 Ibidem, s. 373-400.

$10 \quad$ M. Nussbaum, $W$ trosce..., s. 52-53.

11 „Ponieważ humanistyka powinna się zajmować twórczością, nietwórczość profesorów stanowi w tej dziedzinie upośledzenie." A. Bloom, Umyst..., s. 447. 
Allan Bloom zdecydowanie opowiada się za elitaryzmem uniwersytetu ${ }^{12}$. W egalitaryzmie, wyrażanym poprzez wyrażenia takie jak „indywidualny rozwój każdego" czy "tworzenie atmosfery sprzyjającej nauce”, tak gloryfikowanym w edukacji liberalnej, dopatruje się zrównania mądrych i głupich, co hamuje rozwój prawdziwych talentów. Utożsamia go z konformizmem, z usprawiedliwianiem braku samodzielnego szukania odpowiedzi na pytania - w zamian możemy zaspokoić się wartościami, które wyznają "wszyscy" i które "nikomu nie wadzą”. Nadto uważa, że uniwersytet powinien zachować dystans względem mas i nie być podatnym na żadnego rodzaju zmiany, które toczą się w społeczeństwie, gdyż jego rolą jest pozostawanie ostoją rozumu, niezależenie od wydarzeń ${ }^{13}$. Zagrożenia wynikające ze zrezygnowania z elitarności uniwersytetu oddaje najlepiej cytat: „pospolitość, jaka występuje w społeczeństwie, zadusi delikatne roślinki, które uniwersytet pielęgnuje w szklarni dla potrzebujących innego pożywienia"14.

Z kolei Nussbaum opowiada się wyraźnie za egalitaryzmem, opierając swój pogląd na twierdzeniu o tym, iż prawda, filozofia nie jest ze swej natury elitarna. Jest przekonana, iż każdy, kto zechce, może się do niej zbliżyć, a osiągnąć ten stan można jedynie poprzez traktowanie problemów - zwłaszcza problemów innych kultur - jako bliskich sobie. Kosmopolityzm jest kluczem do poznania prawdy, ponieważ wszyscy jesteśmy obywatelami świata. Idąc tropem zaproponowanym przez Nussbaum, należałoby oprzeć nauczanie na metodzie sokratejskiej. Dzięki temu możliwe byłoby efektywniejsze skupienie się na indywidualnym rozwoju każdego ze studentów ${ }^{15}$. Podążając konserwatywnym tropem, należałoby zmniejszyć liczbę przyjęć oraz zwiększyć stopnień trudności egzaminu magisterskiego, aby ograniczyć liczbę bezwartościowych osób dzierżących jedynie tytuł, a nie legitymujących się konkretną wiedzą czy naukowymi dokonaniami.

Jak pisze Allan Bloom: ,jeżeli ktoś chce być wykształcony, pewne rzeczy wiedzieć musi"16. Wskazuje on tym samym na konieczność istnienia kanonu lektur, które każdy powinien przeczytać i poddać się związanemu z nimi namysłowi. Argumentuje, iż klasycy poszerzają horyzonty umysłowe i stawiają prowokacyjne pytania, ujawniając nawzajem niedoskonałości swoich teorii ${ }^{17}$. Pomagają się one

12 Zauważa tym samym, że na amerykańskich uczelniach trudno jest się go doszukiwać - gdyż nawet opozycja kultury niskiej i wysokiej została już zniesiona. Por. A. Bloom, Umyst..., s. 381.

13 Ibidem, s. 374.

14 Ibidem, s. 383.

15 M. Nussbaum, $W$ trosce..., s. 40-46.

16 A. Bloom, Umyst..., s. 382.

17 Pomagają one również spełniać jedno z podstawowych wg Blooma zadań uniwersytetu - jakim jest stawianie w centrum uwagi wiecznych pytań. Por. ibidem, s. 300. 
również odnaleźć początkującym geniuszom, ponieważ zaszczepiają w nich świadomość pytań, które są istotne dla rozwoju myślenia. Zwraca przy tym uwagę, by egzegeza odbywała się zgodnie z intencją autora, gdyż przeinaczanie sensów czy doszukiwanie się - jak czyni chociażby szkoła frankfurcka - „drugiego dna” wypacza istotę i myśli dawnych geniuszy ${ }^{18}$. Postuluje również, żeby uniwersytet nie bał się przedstawiać doktryn politycznych powstałych na przestrzeni wieków. Pusta apolityczność, unikanie ryzyka problemu indoktrynacji poprzez pozbawienie programu treści doktrynalnych w ogóle prowadzi do podatności na radykalizmy i braku autorefleksji nad obraną drogą w świetle innych możliwości ${ }^{19}$. Podobnie jak dla Blooma - dla Nussbaum najważniejsze jest wielostronne spojrzenie na problemy, jednakże postuluje ona, iż kanon byłby ograniczający per se. Proponuje w zamian czytanie tego, co wywołuje powszechną reakcję, porusza kontrowersyjne tematy i stawia odważne, aktualne tezy ${ }^{20}$. Zwraca uwagę na konieczność rozwijania współczucia w studentach - jako jedynej możliwej drogi do zrozumienia drugiego człowieka oraz na istotną rolę literatury w tym działaniu. Czytelnik podczas lektury poprzez identyfikację z bohaterem, wejście w świat jego przeżyć wewnętrznych uwrażliwia się na obce - zdawałoby się - problemy i staje się bardziej refleksyjny ${ }^{21}$. Ponadto zmieniające się realia wymagają odpowiednich reakcji - również ze strony pisarzy, którzy poruszają aktualne tematy. Nussbaum zwraca też uwagę na to, iż "nudny” kanon zniechęca do czytelnictwa w ogóle. Gdyby Bloom żył, odpowiedziałby zapewne, że osoba, którą w ogóle trzeba zachęcać do czytelnictwa, nie jest godna wyższego wykształcenia. Wcielenie pomysłu Nussbaum w życie, np. poprzez wprowadzenie obowiązkowych zajęć z filozofii i w ramach nich - programu czytania różnych lektur przyczyniłoby się do pogłębienia chaosu o którym wspomina Bloom odnośnie do demokracji - rynek książkowy jest ogromny i w dzisiejszych czasach zapełnia go wiele zupełnie bezwartościowych pozycji-które nie realizowałyby nawet liberalnej idei o rozwoju współczucia, ze względu na swoją jałowość i płytkość. Z kolei nakaz czytania chociażby klasyków mógłby się przyczynić do lepszego zrozumienia siebie i poznania pytań - nie można mieć wątpliwości co do merytorycznej wartości dzieł, uznanych przez setki lat - lecz bez odpowiedniej prezentacji, bez zaciekawienia lektura pozostałby jedynie przykrym w oczach studenta obowiązkiem.

\footnotetext{
18 Ibidem, s. 449.

19 Brak jasnej prezentacji wytyczonych przez minione pokolenia ścieżek, ich osiągnięć i błędów $\mathrm{w}$ tej materii pozostawia w umyśle młodego człowieka pustkę, czyniąc go nieodpornym na hasła odwołujące się do najniższych instynktów. Por. ibidem, s. 422.

20 M. Nussbaum, W trosce..., s. 111.

21 Proces ten Nussbaum określa za Boothem mianem „kodukcji” (coduction) - co ma podkreślać jego „wspólnotowy i porównawczy charakter”. Por. ibidem, s. 112.
} 
Wprowadzenie nowych kursów jest przedmiotem ostrej krytyki Blooma i postulatem Nussbaum. Amerykanka proponuje, aby przynajmniej jeden kurs na temat obcych kultur lub innych orientacji seksualnych był obowiązkowy. Według niej świadomość różnic sprzyja wzajemnemu poszanowaniu oraz kreuje poczucie wspólnotowości. W książce W trosce o społeczeństwo postuluje również naukę przynajmniej jednego języka z obcej grupy oraz konieczność poznania i rozumienia przynajmniej podstaw największych religii świata ${ }^{22}$. Przedstawia również realizowany już na niektórych uczelniach program women's studies, które mają służyć „wyzwoleniu się od tyranii kulturowych nawyków”23. Allan Bloom uważa, iż hasło „poznaj inną kulturę” jest jedynie pustym sloganem, używanym przez uniwersytety w celach wyłącznie PR-owskich. Tym samym zdaje się demaskować rolę innowacyjnych przedmiotów - jest to jedynie zabieg marketingowy, mający przyciągnąć jak największą liczbę studentów - zwiększając zasobność portfeli pracowników uczelni. Wskazuje przy tym na fakt, iż przedmioty, których wprowadzenie postuluje edukacja liberalna, zależą od mody w danym momencie ${ }^{24}$. Prawdą jest, iż również Nussbaum nie wypowiada się w żadnym miejscu swojej polemiki, które konkretnie przedmioty należałoby wprowadzić spośród multum propozycji. Bloom ponadto ukazuje hipokryzję podążania za daną modą. Przywołuje przykład młodych osób, które, martwiąc się o polowania na jelenie, zarazem bronią prawa do aborcji ${ }^{25}$. Oblicze uniwersytetu, które nie wskazuje żadnej właściwej drogi postępowania, staje się przez to niewyraźne, a młodzi ludzie - również ci zdolni - coraz bardziej zagubieni. Uczelnie zostały zdominowane przez walkę z rasizmem, seksizmem czy elitaryzmem, zapominając o swoich podstawowych celach.

Jak powyższe postulaty mogłyby, czy też może - są realizowane w polskiej edukacji prawniczej? Zanim odpowiem na to pytanie, należy przyjrzeć się miejscu i roli kształcenia prawniczego u obu omawianych filozofów. Allan Bloom uważa, iż nauka prawa, medycyny i przedmiotów inżynieryjnych - które zawiera w pojęciu „nauk stosowanych”, są dyscyplinami o niższej godności, ale za to wysoce pragmatycznymi. Wprowadza również rozróżnienie na nauki dążące do wiedzy - są to np. filozofia, matematyka czy chemia, oraz te, których celem jest dobrobyt - wśród

22 Ibidem, s. 78-83.

23 Na poparcie tej tezy Nussbaum przywołuje wyniki obserwacji zachowania rodziców względem niemowlaków, z których wynika, iż ich postawa - np. poczytywanie płaczu za przejaw agresji u chłopca, a strachu u dziewczynki - jest odgórnie podyktowana im przez wszechobecne wzorce kulturowe. Por. ibidem, s. 204.

24 „Student musi więc lawirować pomiędzy chmarą karnawałowych naganiaczy, z których każdy zachęca ich do oglądnięcia jakiegoś konkretnego widowiska". A. Bloom, Umyst..., s. 405.

25 Moda pozwala tym ludziom ignorować powstałą w ten sposób wewnętrzną sprzeczność, a nawet zachęca, by się nią afiszować. Por. ibidem, s. 202. 
których wymienia między innymi prawo. Co ciekawe, właśnie mniej godne dyscypliny tworzą fasadę uniwersytetu, gdyż tylko one są dostępne i zrozumiałe dla osób z zewnątrz, ponieważ unikają w swojej naturze abstrakcyjności, dotyczą codziennych, powszechnych problemów ${ }^{26}$. Jednocześnie przy okazji poruszania tematu edukacji liberalnej, stwierdza on, iż „na różnych kursach liberalnych częściej widuje się przyszłych prawników, ponieważ szkoły prawnicze mają mniej sprecyzowane wymagania, stawiając na studentów inteligentnych" ${ }^{27}$. Mniejszy stopień dookreślenia wymagań sprawia, iż w collage'u student prawa może sobie pozwolić na dodatkowe zajęcia, jeżeli akurat one go zainteresują. Wydaje się to jednak wynikać $\mathrm{z}$ amerykańskiej dwustopniowej, a nie jednolitej struktury studiów. Jednakże omówione powyżej postulaty Blooma są częściowo realizowane w rodzimej edukacji prawniczej. Wszechobecna hierarchia jest zdecydowanie silniejsza niż w USA, gdzie chociażby zwyczajowo do nauczyciela zwraca się „You” - w Polsce wymagana jest oficjalna nomenklatura wraz z podaniem tytułu rozmówcy. Postulat Nussbaum o integracji studentów z nauczycielami jest niemożliwy z tego właśnie względu. Ogromna liczba studentów prawa (które jest jednym z najchętniej wybieranych rokrocznie przez studentów kierunków, pomimo mediów spekulujących o bezrobociu absolwentów) zdaje się świadczyć o egalitaryzmie. Podobnie zmiany wprowadzone tzw. ustawą Ziobry miały przyczynić się do łatwiejszego dostępu do aplikacji. Jednakże w praktyce ani wizja Blooma, ani wizja Nussbaum nie jest realizowana-dostęp do studiów prawniczych jest obecnie bardzo łatwy. Tryb zaoczny lub też uczelnie prywatne są otwarte na każdego, kto jest tylko w stanie pokryć czesne. Elitarność rozpoczyna się dopiero na etapie aplikacji, jednakże z pewnością nie jest to elitarność w rozumieniu Allana Blooma - droga do zawodu jest utrudniana również zdolnym studentom. Aby wypełnić wolę Blooma w tym zakresie, należałoby zmniejszyć liczbę przyjęć np. poprzez przywrócenie egzaminów wstępnych, które określałyby predyspozycje do podjęcia zawodu prawniczego.

Ponadto nauczane przedmioty winny być ściśle określone - niedopuszczalne byłoby np. realizowanie jedynie jednego z trzech zagadnień historyczno-prawnych, jak jest np. na Uniwersytecie Jagiellońskim. Opozycyjna propozycja na gruncie polskim oparłaby się na tworzeniu innowacyjnych kursów, które lepiej odpowiadałyby rzeczywistości - np. przedmioty związane z rozwojem Internetu i prawnym ujęciem problemów z nim związanych lub wprowadzenie obowiązkowego kursu nt. innej kultury. Zakładając kompetencję prowadzących, tego typu zabieg mógłby przynieść korzyści. W pewnym sensie postulat jest realizowany - poprzez obo-

\footnotetext{
26 Ibidem, s. 311.

27 Ibidem, s. 443.
} 
wiązkowe nauczanie języków obcych, jednak większość studentów ogranicza się jedynie do europejskiej grupy językowej.

Nussbaum wprost wypowiada swoje postulaty co do prawników - uważa, iż jest to zawód wymagający szczególnej wrażliwości, gdyż rozstrzygają oni sprawy osób zupełnie innych od siebie - w tym również np. mniejszości seksualnych czy narodowych. Jako przykład wskazuje profesora, który, prowadząc zajęcia z prawa karnego, czyni odwołania do rapu i omawia całą związaną z nim subkulturę ${ }^{28}$. Tego typu podejście pomogłoby uniknąć jawnego krzywdzenia niewinnych osób, z drugiej jednak strony sądy są równie często krytykowane za zbytnią pobłażliwość dla sprawców najcięższych przestępstw. Powodzenie tego typu przedsięwzięcia w polskiej edukacji prawniczej wydaje się zatem wysoce wątpliwe. Można stwierdzić, iż w kwestii innowacyjnych kursów polskie rozwiązania są bliższe Bloomowi. Przeszczepiając omawiane koncepcje na grunt wykładni prawniczej w opcji liberalnej, nacisk zostałby zapewne położony na wykładnię dynamiczną, jako najlepiej odpowiadającą aktualnym, omawianym wydarzeniom. Podążając konserwatywnym tropem, wykładnia byłaby statyczna i dążyłaby do jak najwierniejszego odtworzenia intencji prawodawcy. Z kolei kanonu lektur należy doszukiwać się na etapie szkoły średniej - podczas 5 lat studiów prawniczych możliwe jest, by student nie sięgnął do żadnej książki poza podręcznikami - gdyż nikt go do tego ani nie zachęca, ani nie zmusza. Jeżeli wcześniejsze kształcenie nie wytworzy w nim samym chęci do czytelnictwa, to studia zdecydowanie tego nie zmienią. Pozycje obecne w kanonie, niezbędnym do zdania egzaminu maturalnego, stanowią zamknięty, wyselekcjonowany zbiór, jednakże w swojej istocie jest on bliższy Nussbaum. Lektury te bowiem przede wszystkim odwołują się do uczuć i budują wrażliwość ${ }^{29}$. $Z$ drugiej strony warto zwrócić uwagę na fakt, iż przez całą edukację - włącznie ze studiami - uczeń w Polsce może przejść bez zapoznania się z tekstem któregokolwiek z wielkich filozofów. Obowiązkowa Teoria i filozofia prawa jedynie częściowo rozwiązuje ten problem. Na taki stan rzeczy z pewnością nie zgodziliby się ani Bloom, ani Nussbaum, pomimo sporu jak i które teksty myślicieli należałoby czytać. Oby jednak Bloom nie miał racji, twierdząc, że „nad bramą humanistyki widnieje wielojęzyczny napis: Prawdy nie ma - przynajmniej tutaj"30.

28 M. Nussbaum, W trosce..., s. 221-222.

29 Zob. Komunikat dyrektora CKE w sprawie listy lektur dla szkół ponadgimnazjalnych na egzamin maturalny od maja 2009 roku, http://www.cke.edu.pl/images/stories/Komunikaty_08_09/lektury_2009_matura_a.pdf (15.01.2016) - warto zwrócić uwagę na przeważającą liczbę lektur powstałych $\mathrm{w}$ dobie romantyzmu.

30 A. Bloom, Umyst..., s. 445. 


\section{EMILIA LIV KOPEĆ}

\section{Bibliografia}

Bloom A., Umyst zamknięty - o tym, jak amerykańskie szkolnictwo wyższe zawiodło demokrację i zubożyło dusze dzisiejszych studentów, Poznań 1997.

Galston W.A., Socratic Reason and Lockean Rights. The Place of the University in a Liberal Democracy, "Interpretation - a Journal of Political Philosophy” 1988, 1, 6.

Jaffa H.V., Humanizing Certitudes and Impoverishing Doubts, "Interpretation - a Journal of Political Philosophy" 1988, 1, 6.

Master R.D., Philosophy, Science, and the Opening of the American Mind, "Interpretation - a Journal of Political Philosophy" 1988, 1, 6.

Morrisey W., How Bloom Did It „Interpretation - a Journal of Political Philosophy” 1988, 1, 6.

Neumann H., The Closing of the Philosophic Mind, "Interpretation - a Journal of Political Philosophy" 1988, 1, 6.

Nussbaum M., W trosce o człowieczeństwo - klasyczna obrona reformy kształcenia ogólnego, Wrocław 2008.

Nussbaum M., Undemocratic Vistas, http://www.nybooks.com/articles/archives/1987/ nov/05/undemocratic-vistas/ (15.01.2016).

Stone R.L., Essays on Closing of the American Mind, Chicago 1989. 